\title{
Ethnomedicinal Utilization of Zingiberaceae in the Valley Districts of Manipur
}

\author{
Ningombam Babyrose Devi ${ }^{1}$, P.K. Singh ${ }^{2}$, Ajit Kumar Das ${ }^{3}$ \\ ${ }^{1}$ Department of Ecology and Environmental Sciences, Assam University, Silchar, Assam, India \\ ${ }^{2}$ Centre of Advanced Study in Life Sciences Department of Life Sciences, Manipur University, Chanchipur, \\ Imphal, Manipur, India \\ ${ }^{3}$ Department of Ecology and Environmental Sciences, Assam University, Silchar, Assam, India
}

\begin{abstract}
Zingiberaceae is one of the largest families of the plant kingdom with 53 genera and over 1300 species. About 80 species are mainly distributed in Eastern Himalaya to Southern China, India and SouthEastern Asia, 22 genera and 178 species are recorded in India, 9 genera and 70 species in South India. Out of 19 genera and 88 species available in North East India, 42 species have been recorded from Manipur State. Out of which 24 species were recorded to have ethnomedicinal value in the valley districts of Manipur.
\end{abstract}

Keywords: ethnomedicinal, Manipur, valley districts, Zingiberaceae

\section{Introduction}

Plants are an integral part of life in many indigenous communities. Besides, being the source of food, fodder, fuel, etc., the use of plants as herbal medicines in curing several ailments goes parallel to the human civilization. Manipur mainly comprises of hilly terrain surrounding a centrally located saucer shaped valley of $1856 \mathrm{Sq}$. Km. There are 9 administrative districts in the state in which Imphal East, Imphal West, Bishnupur and Thoubal district forms the centrally located valley portion of Manipur. The water bodies and wetlands of Manipur are lakes, marshes, swamps, canals, rivers, streams and low lying wetland [ 1 ]. The Zingiberaceae plant species play an important ecological role in the understorey of tropical and subtropical forests where many species are quite common [ 2 ]. In some cases the plant forms large stands in the understorey along forest margins and in light gaps while other species are dominant in wetlands and water courses [ 3 ].

Zingiberaceae plant species is also an important natural resource that provides useful products for food, spices and condiments, medicines, dyes, perfumes and aesthetics to man. This plant is cultivated for its rhizome in tropical areas of South and East India [ 4 ] Family Zingiberaceae consists of a large number of medicinal plants and is well known for its ethnomedicine [ 5 ]. Few ginger varieties such as Zingiber cassumunar, Zingiber zerumbet are used in indigenous folk medicines. Many species are economically important plant and also a source for income generation [ 6 ]. Curcuma caesia, Curcuma angustifolia, Hedychium spicatum, Hedychium coronarium are the crops of wild species of Manipur which have great potential [ 7 ].. Hedychium is the largest genus of the family Zingiberaceae in India with about 44 taxa, mostly restricted to North-Eastern states [ 8 ]. Hedychium aureum, Hedychium dekianum, Hedychium robustum are threatened ornamental species of this group [9].

\section{Methodology}

Extensive field surveys were conducted in the different area of Imphal East, Imphal West, Thoubal and Bishnupur districts. The plant specimens were collected and identified with the help of available literature and a voucher specimen of each has been deposited at the herbarium of Life Sciences, Manipur University [ 10, 11, 12 ]. Field information regarding their habit, habitat, dominance, local uses and their ethno-medicinal uses are based on personal observation and detailed discussions with the tribes inhabiting these areas, particularly the aged people and local tribal medical practitioner during the regular field surveys.

Table 1. Uses of the plant species of Zingiberaceae in the Valley districts of Manipur.

\begin{tabular}{|l|l|l|}
\hline \multicolumn{1}{|c|}{ Scientific name } & \multicolumn{1}{|c|}{ Parts used } & \\
\hline Alpinia galanga (L.) Willd. & Rhizomes & Spice and condiments and is an abortifacient. \\
\hline Alpinia officinarum Hance. & Rhizomes & Stimulant, spice and food flavoring agent. \\
\hline Alpinia nigra (Gaertn) Burtt. & $\begin{array}{l}\text { Rhizomes and young tender } \\
\text { shoots }\end{array}$ & Tonic, spice and food flavoring agent. \\
\hline Amomum aromaticum Roxb. & Seed and young shoots. & Condiment and food flavoring agent. \\
\hline Amomum subulatum Roxb. & Seeds & Food additives for flavoring and masticatory. \\
\hline Curcuma amada Roxb. & Rhizomes & Coloring agent and used on sprains. \\
\hline
\end{tabular}


Ethnomedicinal Utilization Of Zingiberaceae In The Valley Districts Of Manipur

\begin{tabular}{|c|c|c|}
\hline Curcuma angustifolia Roxb. & Inflorescence and rhizomes & Vegetable and food flavoring agent \\
\hline Curcuma aromatica Salisb. & Rhizomes & Substitute of turmeric. \\
\hline Curcuma caesia Roxb. & Rhizomes & Cough, sprains, bruises. \\
\hline Curcuma longa $\mathrm{L}$. & Rhizomes, leaves & Tonic, stimulant, blood purifier, spice and dyes. \\
\hline Curcuma leucorrhiza Roxb. & Rhizomes & Cough. \\
\hline Hedychium coronarium J. Koenig. & Rhizomes & Vomiting. \\
\hline $\begin{array}{l}\text { Hedychium coccineum Buch.-Ham. ex } \\
\text { Sm. }\end{array}$ & Flowers & Ornamental \\
\hline Hedychium flavum Roxb. & Young tender shoots. & Vegetable and as food flavoring agent. \\
\hline Hedychium flavescens Carey ex Roscoe & Flowers & Ornamental \\
\hline Hedychium marginatum C.B. Clarke. & Flowers & Ornamental \\
\hline Hedychium spicatum $\mathrm{Sm}$. & Flowers & Ornamental \\
\hline Hedychium stenopatalum Lodd. & Flowers & Ornamental \\
\hline Kaempferia galanga $\mathrm{L}$. & Flowers and rhizomes & Ornamental and medicine \\
\hline Kaempferia rotunda $\mathrm{L}$. & Roots and tubers & Swelling and mumps. \\
\hline Zingiber cassumunar Roxb. & Rhizomes & analgesic \\
\hline $\begin{array}{l}\text { Zingiber montanum (J.König) Link ex A. } \\
\text { Dietr. }\end{array}$ & Rhizomes & Cough and headache \\
\hline Zingiber officinale Roscoe. & Rhizomes & Spice, and condiments, cold, coughs. \\
\hline Zingiber zerumbet (L) Rosc.ex Sm. & Flowers & Ornamental \\
\hline
\end{tabular}

Table 2. Distribution of Zingiberaceae plant species in the Valley Districts of Manipur.

\begin{tabular}{|c|c|c|c|c|}
\hline Scientific name & Imphal East & Imphal West & Thoubal & Bishnupur \\
\hline Alpinia galanga (L.) Willd. & + & - & - & - \\
\hline Alpinia officinarum Hance. & + & - & - & - \\
\hline Alpinia nigra (Gaertn) Burtt. & + & - & - & + \\
\hline Amomum aromaticum Roxb. & + & - & - & + \\
\hline Amomum subulatum Roxb. & + & - & - & - \\
\hline Curcuma amada Roxb. & + & - & - & - \\
\hline Curcuma angustifolia Roxb. & + & - & - & + \\
\hline Curcuma aromatica Salisb. & + & - & - & - \\
\hline Curcuma caesia Roxb. & + & + & - & - \\
\hline Curcuma domestica Valeton & + & + & - & - \\
\hline Curcuma leucorrhiza Roxb. & + & - & - & - \\
\hline Hedychium coronarium J. Koenig. & - & - & - & + \\
\hline $\begin{array}{l}\text { Hedychium coccineum Buch.-Ham. } \\
\text { ex Sm. }\end{array}$ & + & - & - & - \\
\hline Hedychium flavum Roxb. & - & - & - & + \\
\hline $\begin{array}{l}\text { Hedychium flavescens Carey ex } \\
\text { Roscoe }\end{array}$ & + & - & - & - \\
\hline $\begin{array}{l}\text { Hedychium marginatum } \\
\text { Clarke. }\end{array}$ & - & + & - & - \\
\hline Hedychium spicatum $\mathrm{Sm}$. & - & - & + & - \\
\hline Hedychium stenopatalum Lodd. & + & - & - & - \\
\hline Kaempferia galanga $\mathrm{L}$ & + & - & - & - \\
\hline Kaempferia rotunda $\mathrm{L}$. & + & + & - & - \\
\hline Zingiber cassumunar Roxb. & + & - & - & - \\
\hline $\begin{array}{l}\text { Zingiber montanum J. Koenig Link } \\
\text { ex A. Dietr. }\end{array}$ & + & - & - & - \\
\hline Zingiber officinale Roscoe. & + & + & + & + \\
\hline Zingiber zerumbet (L) Rosc.ex Sm. & - & + & - & - \\
\hline
\end{tabular}

\section{Result}

The present work involves the study of a total number of 24 species of 6 genera. Traditional uses of rhizomes, leaves, flowers and tubers of 24 speicies are used by both local and tribal community has been recorded (Table 1), out of which, 13 species of them are generally used as vegetable. Among these 10 species of them are sold at market having economic value. Hedychium species, Kaempferia species are also an important ornamental plant apart from its high medicinal value. The diversity of the species is shown in Table 2. It shows the presence and absence of the flora in the area. 


\section{Discussion}

Importance of the indigenous plant species of Zingiberaceae in our lives, their production and consumption is still negligible by our general lack of awareness in all sectors of the society and a lack of the necessary capacity within the scientific community. moreover, it is also noticed that due to population explosion, gradual urbanization, forest encroachment for agricultural and human settlement in the forest land especially in the buffer zone by the socio- economically poor people, lead to the gradual deforestation and ultimately extinction of many medicinally and economically important plants. During the last decades, the forest has been degraded as a consequence of heavy tree felling, collection of fire woods, thatch and fodder, medicinal plants and extinction of many floras, unstable political situations and poor socio- economic condition of people. Most of them are very rich source of carbohydrates, fat, proteins, phosphorus, potassium and dietary fibre and provides energy. They have a definite role in alleviating hunger, nutrient deficiencies, preventing many diseases and also leading to less seasonality in vegetable production. If the local people are made aware of the importance and marketing potentials of economically important plants and also train up them for organised cultivation and marketing, then it will definitely help not only in conservation but also for the upliftment of economic condition of the local poor people of those areas.

There is a scope for collection and documentation of these plant species. So, the present study would emphasize to study the flora of Zingiberaceae in the valley districts of Manipur which would help in conservation of the existing diversity and to protect such potentially useful economic plant wealth for present use and for prosperity.

\section{References}

[1] Prakash, V. and Mehrotra, B.N. (1996). Zingiberaceae of Northeast India: diversity and taxonomic status. Proceedings of the $2^{\text {nd }}$ symposium of the family Zingiberaceae: 262-273.

[2] Pandey, P.C. and Samant, S.S. (eds) (2001). Plant Diversity of the Himalaya: pp 101-118. Gyanodaya Prakashan Nainital.

[3] Kress,W.J Prince, L.M. and Williams, K. J. (2002). The phylogeny and a new classification of the gingers (Zingiberaceae): evidence from molecular data. American J. Bot. 89:: 1682-1696.

[4] Bhunia, D. and Mondal, A.K. (2012). Antibacterial activity of Alpinia L. (Zingiberaceae) from Santal and Lodha Tribal areas of Paschim Medinipur Districts in Eastern India. Advances in Bioresearch 3 (1): 54-63.

[5] Tushar, B. S., Sarma, G.C. and Rangan, L. (2006). Ethnomedicinal uses of Zingiberaceous plants of Northeast India. J. Ethnopharmacology 132 Ham- An overview. (1): 286-296

[6] Sukumar, S.S. (2009). The economic plants of Manipur and their uses. pp 28-85.

[7] Sravani, T. and Paarakh, P.M. (2011). Hedychium spicatum Buch- Ham. Pharmacologyonline 2: 633-642.

[8] Sanoj, E. and Sabu, M. (2001). The identity of Hedychium marginatum C.B.Clarke (Zingiberaceae), and a new species, H. nagamiense form North-Eastern India. Bangladesh J.Plant taxon 18(2): 169-176.

[9] Singh, J.S., Batra, V.K., Sanjive, K.S. and Thiyam, J.S. (2012). Diversity of underutilized vegetable crops species in North-East India with special reference to Manipur: A review. Nebio 3 (2): 87-95.

[10] Deb, D.B. (1961). Monocot and Dicot plants of Manipur 3: pp 119-120.

[11] Sinha, S.C. (1996). Medicinal plants of Manipur.

[12] Larsen,K. and Delin, W. (2000). Flora of China 24:322-377. 